\title{
The Digital Transformation of the Public Sphere, Its Features in the Context of Various Political Regimes, and Its Possible Influence on Political Processes
}

\author{
Alexey Salikov \\ $\mathrm{PhD}$, Leading Research Fellow, Centre for Fundamental Sociology, \\ National Research University - Higher School of Economics \\ Address: Myasnitskaya str., 20, Moscow, Russian Federation 101000 \\ E-mail: dr.alexey.salikov@gmail.com
}

\begin{abstract}
The question of how the digital transformation of the public sphere affects political processes has been of interest to researchers since the spread of the Internet in the early 1990 os. However, today there is no clear or unambiguous answer to this question; expert estimates differ radically, from extremely positive to extremely negative. This article attempts to take a comprehensive approach to this issue, conceptualizing the transformations taking place in the public sphere under the influence of Internet communication technologies, taking their political context into account, and identifying the relationship between these changes and possible transformations of political regimes. In order to achieve these goals, several tasks are tackled during this research. The first section examines the issue as to whether the concept of the public sphere can be used in a non-democratic context. It also delineates two main types of the public sphere, the "democratic public sphere" and the "authoritarian public sphere," in order to take into account the features of public discourse in the context of various political regimes. The second section discusses the special aspects of the digital transformation of the public sphere in a democratic context. The third section considers the special aspects of the digital transformation of the public sphere in a non-democratic context. The concluding section summarizes the results of the study, states the existing gaps and difficulties, outlines the ways for their possible extension, and raises questions requiring attention from other researchers.
\end{abstract}

Keywords: public sphere, democratic public sphere, authoritarian public sphere, internet, digitalization, transformation, political regime

\section{Introduction}

The question of how the digital transformation of the public sphere affects political processes has been of interest to researchers since the spread of the Internet in the early 1990 s (see, for instance, Dahlberg, 1998; Fountain, 2001; Weare, 2002). However, today there is no clear or unambiguous answer to this question. For a long time, the science was dominated by the paradigm of so-called cyber-optimism (or cyber-utopianism), according to which the development and dissemination of Internet technologies should promote democratization (Gore, 1995; Tsagarousianou et al., 1998; Hacker, van Dijk, 200o;

\footnotetext{
(c) Саликов А. Н., 2019

(c) Центр фундаментальной социологии, 2019
}

DOI: $10.17323 / 1728-192 \mathrm{X}-2019-4-149-163$ 
Ferdinand, 2000) and "constitute a threat to authoritarian regimes" (Kalathil, Boas, 2003: 1). If its use is associated with the success of the mass protest movements of the $2000 \mathrm{~s}$ and early 2010s, the emergence and following boom of social media, in many respects, only seemed to strengthen the position of this paradigm (see, for instance, Diamond, 2010; Shirky, 2011). At some point, it might seem that the process of digitalization of the public sphere should inevitably turn all political regimes on the planet into democracies; then, it would be enough to give the entire population access to the Internet. Therefore, the problem would turn from a political problem into a technical one. However, since the early 2000 s, works began to appear in which the authors were rather pessimistic about the influence of the Internet on politics. These scholars believe that Internet technologies are more likely to harm the development and spread of democracy, and point out a number of negative effects of the Internet in democracies as well as the ability of authoritarian regimes to cope with this technological challenge (Kalathil, Boas, 2001, 2003; Aday et al., 2010; Morozov, 2011; Deibert, 2015). Nowadays, it seems that both paradigms of cyberoptimism and cyber-pessimism provide a somewhat overly-simplified and one-sided picture of the impact that the digital transformation of the public sphere has on politics; in fact, they overlook the complexity and multidimensionality of the influence of Internet technologies on the public sphere (for more on this topic, see also; Deibert, Rohozinski, 2010; Toepfl, 2013: 244; Torres-Soriano, 2013: 1-22), as well as the specific and particular features of political regimes (full democracy, flawed democracy, hybrid regime, and various forms of authoritarian regimes) in the context of which this public sphere exists. This makes us think of the need for a more realistic and multidimensional approach to the public sphere which would proceed from the complexity and multidimensionality of the public sphere where public activities happen, as well as taking the political context into consideration. This complex understanding of the public sphere would have both a theoretical and applied significance. In theoretical terms, such a rethinking of the concept of the public sphere would mean a further departure from Habermas' normative model and the development of a more realistic concept reflecting both the multiplicity and complexity of the public sphere and the political environment in which a public sphere is functional. The applied meaning of such a rethinking of the concept of the public sphere consists in providing the necessary theoretical basis for empirical research on the influence of the Internet on the citizens' public and political activities, and on the connection between these activities and political changes. This study does not pretend to create a new concept of the public sphere, but represents an attempt to contribute to the development of a new approach to its understanding by combining existing data from sociology, communication studies, and political science, and would close the gap between theory and a rapidly-changing reality.

In this article, I will first examine the issue of whether the concept of the public sphere can be used in a non-democratic context. I will also delineate the public sphere into two main types, the "democratic public sphere" (designated as the DPS) and the "authoritarian public sphere" (designated as the APS) in order to take into account the features of public discourse in the context of various political regimes. In the second section, I will 
discuss the special aspects of the digital transformation of the public sphere in a democratic context. In the third section, I will consider the special aspects of the digital transformation of the public sphere in an authoritarian context. In the concluding section, I will summarize the results of the study, state the existing gaps and difficulties, outline the ways for their possible extension, and raise questions requiring attention from other researchers.

\section{The Concept of the Public Sphere in Various Political Contexts}

It is traditionally believed that the concept of the public sphere reflects public communication between various citizens, and between citizens and authorities in a democratic society. This, supposedly, automatically implies that such communication, if it exists, is built on completely different principles in a non-democratic society. Moreover, the very use of the concept of the public sphere in an undemocratic context may not seem entirely legitimate, since the very principles of the classical concept of the public sphere, dating back to Jürgen Habermas's Structural Transformation of the Public Sphere, are inherently deeply democratic and incompatible with authoritarian practices. Therefore, scientists often avoid using the concept of the public sphere in relation to undemocratic countries, especially when it comes to apparent dictatorships and hard authoritarian regimes, or they use neutral substitute terms ("public-at-large" (e.g. Toepfl, 2019)) in order to somehow denote the entirety of various publics existing there. However, this caution does not seem fully justified since it significantly reduces the use of the concept of the public sphere, forcing it to limit the scope of its application exclusively to those political systems that are characterized in political science as full democracies. Because even the public spheres of countries recognized as full democracies (for example, Norway or Iceland) do not entirely correspond to the Habermasian idealistic model of the public sphere, this makes the latter being of little value for empirically-based studies of the public activity, especially on the scale of such large and complex communities as a country's society with its pluralism and contradictions.

Therefore, a more realistic understanding of the public sphere would be to construe it as a large, complex, and constantly developing system - a multiple public sphere, so to speak - consisting of many separate public spaces (publics, environments) in which people (participants) are open (at least within these public spaces) to communication with each other, to the exchange of information, opinions, and the exercising of discursive practices: "The conventional ideal of a unified public sphere and its corresponding vision of a republic of citizens striving to live up to some 'public good' are obsolete. Public life is today subject to 'medievalization', not as Habermas defined it in Strukturwandel der Öffentlichkeit, but in the different sense of a developing and complex mosaic of differently sized, overlapping and interconnected public spheres" (Keane, 1995: 1; see also Fraser, 1990; Asen, 2000; Breese, 2011; Lunt, Livingstone, 2013). Within these groups, communication (including discursive practices) can be carried out in different ways; 
opinions of different participants may not have the same weight, 1 or discursive practices can differ greatly from the normative standard proposed by Habermas. In the discursive ethics developed by Habermas, the discursive practice should be based on a rational and impartial weighing of arguments, be open to all comers, free from lies and coercion, and aim at the rational consensus of all participants in the discourse (1983: 97-101). However, in reality, the discussion is rarely kept within this framework since competitive, adversarial, emotional, irrational, and other moments are usually mixed in. Participants of a discussion can have completely different and often conflicting motivations and goals, the criticality levels of the public can be very different (from completely uncritical to extremely critical), and access to participation in these discussions may not always be open to all. Thus, it seems to be reasonable to broadly define the public sphere, trying to take the whole range of possible publics and relationships between them into account, which, in some aspects, may be more consistent with the theories of the proponents of a participatory public sphere; in other aspects, they can meet liberal, constructionist, or agonistic traditions of public sphere theory (see Schäfer, 2015). In addition, the fact should not be ignored that the border between the public and the private is actually often blurred and uncertain. There are many partially public spaces and semi-public environments that form the so-called "gray" hybrid zone between the public and private spheres (Klinger, 2018), which is also to be taken into account. This hybrid, partially-public zone is growing significantly; in the last years, there is a visible tendency of leaving "broadcast social media" in favor of increasingly popular "narrowcast tools", which makes possible a narrow limitation of addressees and potential audience (messenger services as WhatsApp, Telegram, etc.), or in which messages appear only for a few seconds before they are deleted or inaccessible (Klinger, 2018; see also: Duncan, 2016). This tendency seems to be even more obvious in authoritarian countries, where people are looking for secure places for the exchange of opinions and discussions in order not to be punished for such actions by the ruling regime.

There is no doubt that public communication has its own characteristic features under different political conditions. Nevertheless, the exchange of opinions and the discussion of common issues are integral parts of almost any human society, including a nondemocratic one, although there are many fewer opportunities for this under an authoritarian rule than in liberal democracies. These discussions may take other forms or be critical of the ruling regime to different extents, but they exist, even if they can be marginalized and put out of the political mainstream. This means that, just like in democracies (whether full or flawed), under authoritarian rule there is something that is similar to the public spheres of democracies, a kind of public sphere even if it may differ from the democratic public sphere in many respects. In order to distinguish this phenomenon from the latter, it may be called an "authoritarian public sphere." This kind of public sphere is even further away from the ideal Habermas public sphere than democratic one, which

1 For example, opinions of famous people or leaders of public opinion formally have the same significance as an opinion of an ordinary Internet user; However, in fact, their arguments have different weights in the eyes of the rest of the Internet community. 
also does not fully correspond to the ideal type, is heterogeneous, and can contain various elements and practices, including authoritarian ones (see, for instance, Michaelsen, Glasius, 2018). The APS provides fewer possibilities for open and equal access to discussions of important social issues, and less freedom in open criticism of the authorities and in defending their political views, compared with a democratic one. Nevertheless, the public spheres of non-democracies have a number of common qualities and characteristics which are similar to the public spheres of democracies; they consist of the same or similar elements (various public communities of different types of publics, for example), albeit in different proportions. Moreover, it would be wrong to idealize the public spheres of democracies by claiming that they consist solely of critical publics; many people in liberal democracies are absolutely apolitical and do not participate in political life, and, thus, in a political sense, they represent an uncritical public which just follows the mainstream, a sort of a passively-apolitical, consumption-oriented mass. In addition, some part of the population of democratic countries, in exactly the same way as parts of the population of autocracies and countries with a hybrid regime, is not able to critically evaluate politicians' statements and simply follows the most charismatic leader. The recent growing populism in liberal democracies around the world confirms the validity of this statement. With regard to their critical activity in the public sphere, both groups of population differ little from similar uncritical populations from authoritarian and hybrid regimes. In addition, there are several taboo topics even in the Western liberal democracies, which, even though, they are not officially forbidden, are considered unwelcome and marginal. For this reason, the majority of the population avoids them (for example, some issues around the current migrant crisis in many countries of the EU, the high levels of crime committed by migrants, the resentments of local people regarding Muslims or Islam or against the migration policy of a ruling political and decision-making elite). It can therefore be argued that there are not only many differences between the public spheres of democracies and the public spheres of undemocratic countries, but there are also many similarities. Moreover, it can be assumed that the digitalization of the public sphere seems to lead to a smoothing of these differences, that is, to a kind of hybridization which manifests itself in the fact that the public spheres (and political systems) of democracies acquire some authoritarian traits, while the public spheres (and political regimes) of non-democratic countries acquire some democratic traits.

The first steps in the developing of the concept that characterizes the public sphere in a non-democratic context are already taken by some authors. Alexander Dukalskis uses the concept of the APS in his book The Authoritarian Public Sphere: Legitimation and Autocratic Power in North Korea, Burma, and China, a term that is understood as "a realm of political discussion and information that is dominated and manipulated by the authoritarian regime and/or its allies" (2017: 3-4). According to Dukalskis, the APS "is characterized by the state's efforts to establish its foundations, delineate its boundaries, and monitor its content. The state does this by saturating the public sphere with its legitimating messages and guarding against any unwanted intrusion by potentially dangerous alternative perspectives" (Ibid.). Dukalskis considers the APS as "an inversion of the very 
meaning of a genuine public sphere" (Ibid.). However, I would prefer to define the APS not as the complete opposite of the public sphere itself in its most pronounced "ideal" form described by Habermas (because the complete opposite of the public sphere would be its absence - as is the case with totalitarian rule) but as its special condition in which public discourse in its classical democratic form is possible nonetheless, even if it is often problematic and may take forms deviating from classic democratic patterns. So, for example, public activity can shift to the semi-public and partially-public spaces, and criticism of the ruling elite may become less direct and take more sophisticated forms. Under this approach, public activity under any political conditions could be described in terms of the public sphere, making, of course, the necessary reservations on the particularities of the political regime in which this public activity takes place. Hence, the whole variety of public spheres could be presented as a certain continuum with the DPS at one pole, the APS at the other pole, and some transitional subtypes in-between.

In terms of digitalization, the DPS and the APS should obviously have differences in their transformations because of the various conditions under which public discourse takes place in their respective spheres. On the other hand, as history shows, changes taking place in the public sphere exert an influence on political communication, on political processes, and in some cases, even lead to regime change. The exact correlation between these phenomena has not yet been fully studied. However, the existing theoretical and empirical studies let us to draw some preliminary conclusions about specific aspects of digital transformation in various political contexts. The following two sections will be devoted to considering the features of the digital transformation of the public sphere in democratic and authoritarian contexts.

\section{Digital Transformation of Democratic Public Sphere}

The vast majority of empirical and theoretical studies devoted to various aspects of the influence of digitalization of the public sphere on politics are dedicated to the changes in the public spheres of democratic countries (see, for instance, Ferree et al., 2002; Krueger, 2002; Gibson et al., 2005; Di Gennaro, Dutton, 2006; Gerhards, Schäfer, 2010; Mossberger, Tolbert, 2010; Lindner et al., 2016). An indisputable result of the digital transformation of the public sphere that was noted by almost all researchers was the emergence of many online public spaces. These spaces serve as an alternative to traditional ones, are more open for participation, allowing citizens to "cooperate and express their opinions, and serve as watchdogs over society on a peer-production model" (Benkler, 2006: 177), and to "reorient themselves from passive readers and listeners to potential speakers and participants in a conversation" (213). In other words, the digitalization of the public sphere contributes to the strengthening of the social and political activities of citizens, opens the way for non-professional politicians and public persons (Elmer, Langlois, McKelvey, 2012: 6) as well as for members of those groups for which it was previously closed (Salikov, 2018). At the same time, some scholars note that digitalization maintains the growing fragmentation and isolationism of the public sphere (Bright, 2018; 
Dahlberg, 2007; Papacharissi, 2002; Sunstein, 2009), and contributes to the phenomenon that Cass Sunstein called the "balkanization" of the public sphere (2008). The essence of the Internet-balkanization of the public sphere is that people with similar views tend to form isolated communities and avoid communication with members of other communities (Rasmussen, 2016: 74), "preventing the discussion and the emergence of alternative opinions on certain topics and defending the monopoly of a single opinion as 'objective' Truths" (Salikov, Zhavoronkov, 2018: 27; 2017: 523). Empirical studies confirm the existence of these negative transformations in the public sphere (Colleoni, Rozza, Arvidsson, 2014; Gaines, Mondak, 2009; Garcia et al., 2015). As a result, such communities can form so-called "echo chambers" (Sunstein, 2009) "in which individuals are largely exposed to conforming opinions" (Flaxman et al., 2016: 299), and be marginalized from the mainstream of the multiple public sphere that "can ultimately lead to the even stronger homogenization of views within such groups, to the filtering out of news and information coming in from the outside which does not fit into the world picture of these groups' members, to declaring something false to be true, to the creation of fake news, and to the radicalization of their agenda in order to make themselves heard in the society" (Salikov, 2018: 90-91). These groups can be very critical and even hostile towards other points of view, especially against the mainstream. At the same time, they can be very homogeneous and uncritical towards members of their own communities, especially towards their leaders. Another negative trend in the development of the public sphere under the influence of digitalization is the changes of discursive practices themselves; the spread of hatred (hate speech), aggression, manipulation, mobbing, trolling, bullying, and other phenomena that occurred much less frequently during face-to-face communication and which are very far from Habermas' discourse ethics. In addition, digitalization leads to growing inequalities and imbalances in the level of attention and influence in the public sphere; the opinions of popular bloggers can be considerably more significant for public opinion than the opinions of many ordinary users (Rasmussen, 2016: 75). At the same time, the opinions of celebrities can be perceived completely uncritically and outweigh many of the most reasonable arguments. This means that public discourse in the networked public sphere "is far from democratic, if we understand democracy as the equal distribution of presence and visibility" (Salikov, 2018: 91).

Another important trend actively developing in the public sphere under the influence of the Internet is its hybridization, the merging of the public and the private, the political and the non-political, or what Hannah Arendt called the "rise of the social" (1998: 38). According to Arendt, this 'rise of the social' in the public sphere has dramatic consequences for the latter; "instead of competition between different opinions, the desire to express individuality and to present one's own uniqueness to others is replaced by conformism and the intention to be 'normal', whilst free and spontaneous action is substituted by a "kind of behavior, imposing innumerable and various rules, all of which tend to 'normalize' its members, to make them behave, to exclude spontaneous action or outstanding achievement" (40). As a result, the public sphere has been transforming into "a pseudo-space of interaction in which individuals no longer "act" but "merely be- 
have" as economic producers, consumers and urban city dwellers" (Benhabib, 1997: 4). Empirical studies show that conformism often puts pressure on the free and open expression of opinions, and on the defense of political position in public discourse (Mallinson, Hatemi, 2018). Given the openness and accessibility of information increasing with the digitalization of the public sphere, many people who hold conformist positions prefer to avoid sensitive and hot-button political topics in the politically heterogeneous communities they have close relations with (Mutz, 2006). Thus, many people prefer nowadays "to discuss political topics in closed or semi-closed communities of like-minded people, that is, people with similar political views" (Salikov, 2018: 98). This hybridization of the public sphere, along with the phenomena of its fragmentation, atomization, and polarization, should, in my opinion, inevitably lead to some hybridization of democracies. This is because the deterioration in the quality of public discourse and the quality of communication between different communities should inevitably lead to some degradation of democratic institutions. This degradation leads to the maintenance of the appearance and wide distribution of some authoritarian practices, which will blend with democratic ones and "hybridize" the political regime.

\section{The Digital Transformation of the Authoritarian Public Sphere}

Compared to the number of studies focusing on the digital transformation of the public sphere in democracies, there are significantly fewer studies devoted to non-democratic countries. These studies have been basically grouped around three main topics: 1) the role of the new ICT in organizing opposition protests (see, for instance, Lim, 2012; White, McAllister, 2014; Rød, Weidmann, 2015; Reuter, Szakonyi, 2015); 2) the use of the Internet and social media by authoritarian authorities for control over their countries (see, for instance, Mackinnon, 2011; Pearce, Kendzior, 2012; Hussain, Howard, 2014; Gunitsky, 2015; Han, 2015; King et al., 2017); and 3) attempts of authoritarian regimes to influence the politics in others countries (see, for instance, Aro, 2016; Maréchal, 2017; Tenove et al., 2018; Rid, 2016). In general, the digitalization of an APS has many common traits with a DPS (an increase in the multiplicity of forms of public discourse and ways to participate in it, an increase in civic activity, fragmentation, and hybridization), but it has also its own specifics connected with the state's active intervention in it, its attempts to take the online sphere under its control, or to use new technologies to strengthen its power (Morozov, 2011; Göbel, 2013). Thus, in an authoritarian regime, the digitalization of the public sphere simultaneously strengthens two conflicting trends: 1) an increase in the citizens' political activity, and the appearance of new forms and ways for exchanging opinions; and 2) the growth of the ruling regime's ability to control and influence society.

As for authoritarian regimes, the digitalization of the public sphere essentially represents a special case of the dictator's dilemma, the essence of which is that new technologies carry certain risks for an authoritarian leader. New technologies threaten the loss of control over the population, while the rejection of these technologies would lead to a technical and economic lag behind other countries, which, ultimately, also carries 
not only the loss of a positive image, but also poses the same threat of losing power in the country. Existing authoritarian regimes solve this problem in different ways. Some, like North Korea, restrict their citizens' access to the Internet almost completely, or, the authoritarian regimes in countries like Laos and Turkmenistan do not formally prohibit the Internet but practically inhibit the development of the needed infrastructure, thereby cutting off a significant part of the population from the World Wide Web (Dukalskis, 2017: 147). Others, such as China, Russia, or Saudi Arabia strongly support the development of Internet communications while attempting at the same time to take the online sphere under their complete control and developing sophisticated methods to manipulate it.

It might be supposed that the second option will become the main way to solve the digitalization dilemma for most authoritarian regimes, as evidenced by the rapid development of Internet technologies in many authoritarian countries (Ibid.), considering the fact that the level of Internet penetration in a number of authoritarian countries is higher than the world average, and in some cases it is even one of the highest in the world. The statistics from the Internet World Stats for June, 2019, show that the Internet penetration rate in Qatar is 99.6\%, in Bahrain - 98.6\%, in the UAE - 98.5\%, in Brunei - 94.9\%, in Saudi Arabia - 93.3\%, in Jordan - 86.4\%, in Turkey - 83.3\%, in Azerbaijan - 79.8\%, in Kazakhstan $-78.9 \%$, in Russia $-76.1 \%$, in Iran $-76 \%$, in Belarus $-74.4 \%$, and in Vietnam $-70.3 \%$, which are all significantly higher than the average Internet penetration in the world which is $57.3 \%$, and it is quite comparable with the average penetration level in the two most developed regions of the planet in terms of Internet communication technologies, North America (89.4\%) and Europe (86.8\%).

Given such levels of Internet penetration, it is almost impossible to completely control the whole online sphere and to prevent the formation of autonomous public spaces. Attempts to build a sovereign local network isolated from the global web exist (for example, in North Korea), but its advantages for the ruling regime (controllability) do not outweigh its disadvantages (the lack of access to global sources of information), and ultimately leads to a technological lag, although not as fast as in case of complete blocking. This means that authoritarian regimes, if they do not want to lose in global competition, are forced, at least to a certain extent, to allow the existence of autonomous public spaces, critical discussions, and the exchanges of views on the Internet. Undoubtedly, they will make efforts to limit the scope and quantity of these "islands of freedom", while at the same time establishing certain frames and "red lines" marking dangerous levels for the regime. This, for example, can explain the Telegram phenomenon with its channels and semi-closed publics in Russia, Iran, and some other countries, whose users often are very critical of the ruling regime and go negative on it (Akbari, Gabdulhakov, 2019: 223-231), but, with rare exceptions, avoid serious persecution by the authorities. Moreover, the authorities themselves often use social media (Telegram is here a vivid example), both for a kind of intra-elite communication and for the leaking of information that cannot be officially disseminated and for the formation of public opinion (Salikov, 2019). 
Thus, there are some reasons to assert that authoritarian regimes of the digital era will in a certain sense be "softer" than their predecessors from pre-digital times, allowing a certain degree of freedom within those boundaries in which these freedoms do not pose a danger to the preservation of the ruling regime, and rigidly suppressing all that is dangerous to the regime within this framework. In addition, one cannot ignore another aspect of digitalization that can affect the very nature of the political regime in the long run. As the old political elite, accustomed to the traditional mode of communication, leaves the political scene, they will be replaced by a new political elite belonging to the "digital generation." For this new, "digital" generation of the ruling elite, communication through Internet platforms and social media will be the norm. The new elite will, at least to some extent, share basic "digital" habits and values such as instant access to the Internet, a freer and more open exchange of information and communication between people, a more emotional, spontaneous, and critical way of expressing opinions, etc. This inevitably should lead to more transparent and open political communication, which in the end should cause some certain changes in the public sphere of authoritarian regimes. Consequentially, authoritarian regimes will absorb some democratic traits and hybridize.

\section{Conclusions and Discussion}

This article can be seen as an effort to examine the issue of how the digital transformation of the public sphere is occurring in various political contexts, and to identify the connection between these changes and the transformations of political regimes. In order to achieve these goals, several tasks were tackled during this research. First, I have summarized the results of the studies regarding the influence of Internet technologies on the transformation of the public sphere under different political regimes, and established the main vectors of this transformation. Based on this, I have hypothesized that the main effect of the Internet on the public sphere is its hybridization in many different senses. Secondly, I hypothesize that the digitalization of the public sphere seems to lead to a smoothing of these differences as a result of a kind of hybridization. This manifests itself in the fact that the public spheres (and political systems) of democracies acquire some authoritarian traits, while the public spheres (and political regimes) of non-democratic countries acquire some democratic traits. Thirdly, I associate digitalization with the hybridization of the public sphere (and political regimes). This, in my opinion, leads to the erosion of democratic and authoritarian tendencies in a political regime, democracies acquire some authoritarian features, while autocracies tend to soften and get some democratic traits.

Hopefully, the working hypotheses and analytical findings made in this article will contribute to the further development of a complex and realistic concept of the public sphere which would take into account specifics of the public sphere in various political contexts and move away from its too-normative understanding having a little value for praxis-oriented political studies. In addition, such a broad and universal approach should provide the establishment of a connection between the state of the public sphere and the 
state of the political regime. This connection could serve as a basis for the development of empirical markers for the analysis of actual and predictions of future political transformations. However, my hypotheses need further theoretical verification and development, as well as empirical studies that could verify or correct them. To do this, we primarily need empirical methods to determine the ratio of different types of publics in the public sphere. The thesis about the hybrid nature of the Internet's influence on the transformation of political regimes also needs to be tested. This thesis seems to be true under contemporary circumstances (the growth of right-wing beliefs in liberal democracies, the relative softening of authoritarian regimes, and the spread of hybrid political regimes), but it needs a more special and in-depth study based on a comparative analysis and generalization of extensive empirical material from political regimes of all types.

\section{References}

Aday S., Farrell H., Lynch M., Sides J., Kelly J., Zuckerman E. (2010) Blogs and Bullets: New Media in Contentious Politics. Peaceworks, vol. 65, pp. 1-36.

Akbari A., Gabdulhakov R. (2019) Platform Surveillance and Resistance in Iran and Russia: The Case of Telegram. Surveillance \& Society, vol. 17, no 1-2, pp. 223-231.

Arendt H. (1998) The Human Condition, Chicago: University of Chicago Press.

Aro J. (2016) The Cyberspace War: Propaganda and Trolling as Warfare Tools. European View, vol. 15, no 1, pp. 121-132.

Asen R. (2000). Seeking the "Counter" in Counterpublics. Communication Theory, vol. 10, no 4, pp. 424-446.

Benhabib S. (1997) The Embattled Public Sphere: Hannah Arendt, Juergen Habermas and Beyond. Theoria: A Journal of Social and Political Theory, no 90, pp. 1-24.

Benkler Y. (2006) The Wealth of Networks: How Social Production Transforms Markets and Freedom, New Haven: Yale University Press.

Breese, E. B. (2011). Mapping the Variety of Public Spheres. Communication Theory, vol. 21, no 2, pp. 130-149.

Bright J. (2018) Explaining the Emergence of Political Fragmentation on Social Media: The Role of Ideolog and Extremism. Journal of Computer-Mediated Communication, vol. 23, no 1, pp. 17-33.

Colleoni E., Rozza A., Arvidsson A. (2014) Echo Chamber or Public Sphere? Predicting Political Orientation and Measuring Political Homophily in Twitter Using Big Data. Journal of Communication, vol. 64, no 2, pp. 317-332.

Dahlberg L. (1998). Cyberspace and the Public Sphere: Exploring the Democratic Potential of the Net. Convergence: The International Journal of Research into New Media Technologies, vol. 4, no 1, pp. 70-84.

Dahlberg L. (2007) Rethinking the Fragmentation of the Cyberpublic: From Consensus to Contestation. New Media \& Society, vol. 9, no 5, pp. 827-847.

Deibert R. (2015) Authoritarianism Goes Global: Cyberspace Under Siege. Journal of Democracy, vol. 26, no 3, pp. 64-78. 
Deibert R., Rohozinski R. (2010) Liberation vs. Control: The Future of Cyberspace. Journal of Democracy, vol. 21, no 4, pp. 43-57.

Diamond L. (2010) Liberation Technology. Journal of Democracy, vol. 22, no 3, pp. 69-83.

Di Gennaro C., Dutton W. (2006) The Internet and the Public: Online and Offline Political Participation in the United Kingdom. Parliamentary Affairs, vol. 59, no 2, pp. 299313.

Dukalskis A. (2017) The Authoritarian Public Sphere: Legitimation and Autocratic Power in North Korea, Burma, and China, London: Routledge.

Duncan F. (2016). So Long Social Media: The Kids are Opting Out of the Online Public Square. Available at: http://theconversation.com/so-long-social-media-the-kids-areopting-out-of-the-onlinepublic-square-53274 (accessed 12 November 2019).

Elmer G., Langlois G., McKelvey F. (2012) The Permanent Campaign: New Media, New Politics, Berlin: Peter Lang.

Fountain J. E. (2001) Building the Virtual State: Information Technology and Institutional Change, Washington: Brookings Institution.

Han R. (2015) Manufacturing Consent in Cyberspace: China's "Fifty-Cent Army". Journal of Current Chinese Affairs, vol. 44, no 2, pp. 105-134.

Habermas J. (1983) Moralbewußtsein und kommunikatives Handeln, Frankfurt am Main: Suhrkamp.

Hacker K., van Dijk J. (200o) What is Digital Democracy?. Digital Democracy: Issues of Theory and Practice (eds. K. L. Hacker, J. van Dijk), London: SAGE, pp. 1-9.

Hussain M. M., Howard P. N. (2014) State Power 2.o: Authoritarian Entrenchment and Political Engagement Worldwide, Farnham: Ashgate.

Internet World Stats (2019). Available at: https://www.internetworldstats.com (accessed 12 November 2019).

Ferdinand P. (ed.) (2000) The Internet, Democracy and Democratization, London: Frank Cass.

Ferree M. M., Gamson W. A., Gerhards J., Rucht D. (2002) Four Models of the Public Sphere in Modern Democracies. Theory and Society, vol. 31, no 3, pp. 289-324.

Flaxman S., Goel S., Rao J. M. (2016). Filter Bubbles, Echo Chambers, and Online News Consumption. Public Opinion Quarterly, vol. 80, no S1, pp. 298-320.

Fraser N. (1990). Rethinking the Public Sphere: A Contribution to the Critique of Actually Existing Democracy. Social Text, no 25-26, pp. 56-80.

Gaines B., Mondak J. (2009) Typing Together?: Clustering of Ideological Types in Online Docial Networks. Journal of Information Technology \& Politics, vol. 6, no 3, pp. 216231.

Garcia D., Abisheva A., Schweighofer S., Serdült U., Schweitzer F. (2015) Ideological and Temporal Components of Network Polarization in Online Political Participatory Media. Policy \& Internet, vol. 7, no 1, pp. 46-79.

Gerhards J., Schäfer M. (2010) Is the Internet a Better Public Sphere?: Comparing Old and New Media in Germany and the US. New Media and Society, vol. 4, no 1, pp. 143160. 
Gibson R.K., Lusoli W., Ward S. (2005) Online Participation in the UK: Testing a "Contextualized” Model of Internet Effects. British Journal of Politics \& International Relations, vol. 7, no 4, pp. 561-583.

Gore A. (1995) Forging a New Athenian Age of Democracy. Intermedia, vol. 22, no 2, p. 4-6.

Göbel C. (2013) The Information Dilemma: How ICT Strengthen or Weaken Authoritarian Rule. Statsvetenskaplig Tidskrift, vol. 115, no 4, pp. 385-402.

Gunitsky S. (2015) Corrupting the Cyber-Commons: Social Media as a Tool of Autocratic Stability. Perspectives on Politics, vol. 13, no 1, pp. 42-54.

Kalathil S., Boas T. C. (2001) The Internet and State Control in Authoritarian Regimes: China, Cuba, and the Counterrevolution. First Monday, vol. 6, no 8. Available at: https://firstmonday.org/ojs/index.php/fm/article/view/876/785 (accessed 12 November 2019).

Kalathil S., Boas T. C. (2003) Open Networks, Closed Regimes: The Impact of the Internet on Authoritarian Rule, Washington: Carnegie Endowment.

King G., Pan J., Roberts M. E. (2017) How the Chinese Government Fabricates Social Media Posts for Strategic Distraction, not Engaged Argument. American Political Science Review, vol. 111, no 3, pp. 484-501.

Klinger U. (2018) Aufstieg der Semiöffentlichkeit: Eine relationale Perspektive. Publizistik, vol. 63, no 2, pp. 245-267.

Krueger B.S. (2002) Assessing the Potential of Internet Political Participation in the United States. American Politics Research, vol. 30, no 5, pp. 476-498.

Lim M. (2012) Clicks, Cabs, and Coffee Houses: Social Media and Oppositional Movements in Egypt, 2004-2011. Journal of Communication, vol. 62, no 2, pp. 231-248.

Lindner R., Aichholzer G, Hennen L. (eds.) (2016) Electronic Democracy in Europe: Prospects and Challenges of E-Publics, E-Participation and E-Voting, Cham: Springer.

Lunt P., Livingstone S. (2013) Media Studies' Fascination with the Concept of the Public Sphere: Critical Reflections and Emerging Debates. Media, Culture \& Society, vol. 35, no 1, pp. 87-96.

Mackinnon R. (2011) Liberation Technology: China's "Networked Authoritarianism". Journal of Democracy, vol. 22, no 2, pp. 32-46.

Mallinson D. J., Hatemi P. K. (2018) The Effects of Information and Social Conformity on Opinion Change. PLoS ONE, vol. 13, no 5, e01966oo.

Maréchal N. (2017). Networked Authoritarianism and the Geopolitics of Information: Understanding Russian Internet Policy. Media and Communication, vol. 5, no 1, pp. 29-41.

Michaelsen M., Glasius M. (2018) Authoritarian Practices in the Digital Age. International Journal of Communication, vol. 12, pp. 3788-3794.

Morozov E. (2011) The Net Delusion: How not to Liberate the World, London: Allen Lane.

Mossberger K., Tolbert C. J. (2010) Digital Democracy: How Politics Online Is Changing Electoral Participation. The Oxford Handbook of American Elections and Political Behavior (ed. J. E. Leighley), Oxford: Oxford University Press, pp. 20o-218. 
Mutz D. C. (2006). Hearing the Other Side: Deliberative Versus Participatory Democracy, Cambridge: Cambridge University Press.

Papacharissi Z. (2002). The Virtual Sphere: The Internet as a Public Sphere. New Media and Society, vol. 4, no 1, pp. 9-27.

Pearce K., Kendzior S. (2012) Networked Authoritarianism and Social Media in Azerbaijan. Journal of Communication, vol. 62, no 2, pp. 283-298.

Rasmussen T. (2016) The Internet Soapbox: Perspectives on a Changing Public Sphere, Oslo: Universitetsforlaget.

Rid Th. (2016) The Plot Against America, Part 1: How Russia Pulled Off the Biggest Election Hack in U.S. History. Esquire, vol. 166, pp. 130-153.

Reuter O. J., Szakonyi D. (2015) Online Social Media and Political Awareness in Authoritarian Regimes. British Journal of Political Science, vol. 45, no 1, pp. 29-51.

Rød E. G., Weidmann N. B. (2015) Empowering Activists or Autocrats?: The Internet in Authoritarian Regimes. Journal of Peace Research, vol. 52, no 3, pp. 338-351.

Salikov A. (2018) Hannah Arendt, Jürgen Habermas and Rethinking the Public Sphere in the Age of Social Media. Russian Sociological Review, vol. 17, no 4, pp. 88-102.

Salikov A. (2019) Telegram as a Means of Political Communication and Its Use by Russia's Ruling Elite. Politology, vol. 95, no 3, pp. 83-110.

Salikov A., Zhavoronkov A. (2017) The Public Realm and Revolution: Hannah Arendt between Theory and Praxis. Estudos Ibero-Americanos, vol. 43, no 3, pp. 513-523.

Salikov A., Zhavoronkov A. (2018) Transformatsiya publichnogo prostranstva v usloviyakh revolyutsii: vzglyad iz perspektivy Khanny Arendt [The Revolutionary Transformation of the Public Realm: An Arendtian Perspective]. Russian Sociological Review, vol. 17, no 1, pp. 9-29.

Schäfer M. S. (2015) Digital Public Sphere. The International Encyclopedia of Political Communication (eds. G. Mazzoleni, K. G. Barnhurst, K. Ikeda, R. C. M. Maia, H. Wessler), London: Wiley Blackwell, pp. 322-328.

Shirky C. (2011) The Political Power of Social Media. Foreign Affairs, vol. 9o, no 1, pp. $28-$ 41.

Sunstein C. R. (2008) Neither Hayek nor Habermas. Public Choice, vol. 134, pp. 87-95.

Sunstein C. (2009). Republic 2.0, Princeton: Princeton University Press.

Tenove Ch., Buffie J., McKay S., Moscrop D. (2018) Digital Threats to Democratic Elections: How Foreign Actors Use Digital Techniques to Undermine Democracy. Research Report, Centre for the Study of Democratic Institutions, University of British Columbia. Available at: https://ssrn.com/abstract=3235819 (accessed 12 November 2019).

Toepfl F. (2013) Making Sense of the News in a Hybrid Regime: How Young Russians Decode State TV and an Oppositional Blog. Journal of Communication, vol. 63, no 2, pp. 244-265.

Toepfl F. (2019) Comparing Authoritarian Publics: The Benefits and Risks of Three Types of Publics for Autocrats. Communication Theory (in press). 
Torres-Soriano M.R. (2013) Internet as a Driver of Political Change: Cyber-Pessimists and Cyber-Optimists. Journal of the Spanish Institute of Strategic Studies, vol. 1, no 1, pp. 1-22.

Tsagarousianou R., Tambini D., Bryan C. (eds.) (1998) Cyberdemocracy: Technology, Cities and Civic Networks, London: Routledge.

Weare Ch. (2002) The Internet and Democracy: The Causal Links between Technology and Politics. International Journal of Public Administration, vol. 25, no 5, pp. 659-691.

White S., McAllister I. (2014) Did Russia (Nearly) Have a Facebook Revolution in 2011? Social Media's Challenge to Authoritarianism. Political Studies Association, vol. 34, no 1 , pp. $72-84$.

\title{
Цифровая трансформация публичной сферы, ее особенности в контексте различных политических режимов и ее возможное влияние на политические процессы
}

\author{
Алексей Саликов \\ Кандидат философских наук, ведущий научный сотрудник Центра фундаментальной социологии \\ Национального исследовательского университета «Высшая школа экономики» \\ Адрес: ул. Мясницкая, д. 20, г. Москва, Российская Федерация 101000 \\ E-mail:dr.alexey.salikov@gmail.com
}

Вопрос о том, какое влияние дигитализация публичной сферы оказывает на политические процессы, притягивает внимание исследователей с момента широкого распространения Интернета в начале 1990-х годов. Однако до сих пор однозначного ответа на этот вопрос нет: оценки экспертов расходятся иногда радикально, от крайне положительных до крайне отрицательных. В настоящей статье предпринимается попытка комплексного подхода к этому вопросу: осмыслить происходящие сегодня под влиянием интернеттехнологий трансформации в публичной сфере с учетом того политического контекста, в котором она происходит, выявить взаимосвязь между этими изменениями и возможными трансформациями политических режимов. Для достижения этих целей в рамках исследования решаются несколько задач. В начале обсуждается вопрос о правомерности использования понятия публичной сферы для анализа публичной активности в недемократическом контексте и делается вывод о необходимости более широкого понимания публичной сферы по сравнению с классическим, восходящим к работам Юргена Хабермаса. Затем в статье рассматриваются особенности цифровой трансформации публичной сферы в условиях демократического режима и делается вывод о возможном характере влияния дигитализации на политическое развитие демократий. После этого анализируются особенности цифровой трансформации в авторитарном контексте и делается вывод о характере влияния дигитализации на политическую трансформацию недемократических режимов. В заключительной части суммируются полученные выводы и намечаются направления для дальнейшего исследования влияния цифровой трансформации публичной сферы на политические процессы.

Ключевые слова: публичная сфера, демократическая публичная сфера, авторитарная публичная сфера, Интернет, дигитализация, трансформация, политический режим 